\title{
Iowa and the Making of a President
}

\author{
By Ora WILLIAMS
}

To THE ANnals EdTor: At the time the Electoral Commission was created in January 1877, already I was deeply interested in national politics. As a youth on our Dallas county farm, between turns at plowing and harvesting, I read much. My father was a Democrat. We took the Weekly New York Sun, and I had access to Henry Watterson's Louisville Courier-Journal and Brick Pomeroy's LaCrosse Democrat. We were for Tilden.

Later, I learned the truth about the 1776 contest, and changed. Governor Packard gave me some accurate insight into details of the matter. The Allison letter went considerably further. Putting all known things together and considering them rightly, the whole story becomes plain. I have long wanted to write it briefly as I know it; now I have done so, and send it along.

Maybe I'm the last man that will ever care; but, arising from a sickbed and warring against intense pain in my $93 \mathrm{rd}$ year, I realize fully that what I am yet to do must be done quickly, for I am in the power reaches of the River of Time, and just beyond the next sharp turn are the rough shoals. But the journey has been one grand adventure, and if the road's last turn is not the best, it certainly is strewn with flowers.

My story is from many sources, picked up partly from along the newspaper row, but a large part is from personal memory reaching back now over seventy years. Sherman Needham's father was one of the publishers of the Oskaloosa Herald, but another was editor, and the paper is on file in the Iowa Historical building at Des Moines.

Memory-what a blessing and a comfort! My thoughts have run back a hundred and more times to the farm where I started and to the mill that my father owned, where "a man named Hoover," from some place "east of Iowa City" operated it, because there were no millwrights nearer; and to the school house where my little feet carried me to school adown the dusty lane. I insisted on going to school with the older children, and had my way.

Then to a farm near the county seat and into a high school in a village of less than a thousand, where I came under the influence of a real teacher-in a town quite small, but a teacher who before he finished had been a member of the faculty of Harvard University, and then was president of 
the University of Southern California. He literally dragged me through high school and enlisted me for a year as his assistant. How fortunate for me!

These and a thousand other similar thoughts crowd in and comfort me on the last lap of my journey. May you and all my friends live long and be happy!-O. W.

\section{Cool Heads Chanced Compromise}

The fascinating task of keeping history straight seems never to have an end. Partisan rancor blurs many pages of the record. This is conspicuous in relation to one of the most dangerous political episodes of American life. After three-quarters of a century the harshness of the political slanders still shows around the edges.

Even now, when the truth long ago should have been accepted, there appear occasional references to President Rutherford B. Hayes as beneficiary of some sort of fraud. That is base slander. Whatever happened, the president did not hold his high office by any other than honorable procedure. He came by his office honestly, and by fair game of American politics as operated on a large but open field. In that grand game, two Iowa men played conspicuous parts, each in a different way, both essential to success.

Let's calmly look at the situation in 1876. In the election just held the opposing party candidates were Governor Hayes of Ohio and Governor Tilden of New York, both high-class and patriotic Americans. The country was nearly evenly divided. In order to make sure of properly conducted elections, the Federal authorities had sent into some states official United States inspectors, with full authority over the elections held. But, from some of these states two sets of returns were sent to Washington, and they were in disagreement.

When congress met the first of December, it faced a dilemma such as never before known and not likely ever to repeat. It was the duty of congress to count the votes as returned and disclose the result. In this procedure, when Florida was reached, the count was 
even, but from that state there were two sets of returns. Which should be recognized and counted? Accompanying them were papers filled with accusations and loud screams about "fraud." So loud was one of these that it was at once disregarded and sent to the junk heap, with branding it's author as a notorious liar.

Now, for congress to send to far away alligator precinct, Dade county, and undertake to find out who had voted wrongly, and perhaps, to some other places, was obviously impossible. But a way must be found for arriving at a fair settlement. The electoral vote of Florida, and possibly of Louisiana, was essential and would be decisive. There might have been wrong-doing down at the edge of the swamps involving a few votes. Noboby now knows, or ever will know. But, no evidence of wholesale thievery. Roughly, perhaps there were 10,000 votes cast in the Florida election, approximately near 5,000 for electors representing each candidate. It could matter little what happened in one or two precincts. Congress simply must find a way of honorable settlement of the contending partisan claims.

Congress Moved To Secure Evimence

The 44th congress was filled with able men; for instance, such as Edmunds, Conkling, Frelinghuysen, Morton, Allison, Blaine, Kasson, Garfield, McCrary, Bayard, and others. They were of a caliber to debate matters without resort to partisan clap-trap. Committees were named to study the question and report on what to do. McCrary of Iowa introduced the resolution adopted in the house to this end and Edmunds in the senate. Finally the select committee of which McCrary was a member, brought forth a bill to create an electoral commission to investigate, ascertain election results and report a measure "best calculated to accomplish a lawful count of the electoral vote, and best disposition of all questions connected therewith, and a due declaration of the results." Senator Edmunds at great length explained the proposed procedure. After debate the bill was immediately passed. It was then late in January 1877, and on January 29th President 
Grant signed and returned it to congress with a brief message of complete indorsement, which included the following paragraph:

The country is agitated. It needs and it desires peace and quiet, and harmony between all parties and all sections. Its industries are arrested, labor unemployed, capital idle and enterprise paralyzed by reason of the doubt and anxiety attending the uncertainty of a double claim to the chief magistracy of the nation. It wants to be assured that the result of the election will be accepted without resistance from the supporters of the disappointed candidate, and that the highest officer shall not hold his place with a questioned title of right. Believing that the bill will secure these ends, I give it my signature.

\section{U. S. Grant}

The president was very moderate in his statement. A band of Kentuckians was lurking in the vicinity of the national capital, polishing their old muskets, awaiting orders from Henry. Watterson, who had declared he would drench the hall of the capitol, if need be, right or wrong, to seat his candidate, the governor of New York. Word was awaited from the Southern state capitals where the old Confederate sabres were being brightened. The time and the occasion called for reopening the bloody strife that once had come so near to destroying the Union. The whole nation was shivering over the swagger, the threats, the wild boasting.

\section{ChIEF Justice Key MaN}

The specially constituted electoral commission met the first of February and set to work at high speed. It was composed of members from both houses of congress and the supreme court of the United States. There were seven Republicans and seven Democrats, plus David Davis, chief justice of the supreme court. Evidently the vote of the chief justice was the key to the result. Who was Davis?

David Davis had been a circuit judge before whom Lincoln as a lawyer had practiced near Springfield. He was one of the Illinois delegates to the convention that nominated Lincoln, who promoted him to the Supreme bench. He was not a Republican. He called 
himself an "independent," but on most political matters landed in the Democrat camp. The Democrats confidently counted on him to cast the deciding vote for their candidate.

Republicans in Iowa CRITICAL

As the situation became more apparent, a murmur of discontent was heard, and it was audible in Iowa. Iowa editors were asking if Allison knew what he was doing when he let the Democrats get away with that one. The Iowa State Register had taken a poll of Republican Iowa editors upon the electoral commission bill procedure and were reported overwhelmingly against it.

The roar was heard in Washington. Senator Allison, of all the Iowans there, was best fitted to know all the outside and the inside of national politics. The journey was a short one from Allison's home in Dubuque to the big brick mansion at the top of the long hill in Galena. Both Republicans and Democrats met at Galena and plotted. Allison knew everything that happened. Allison singled out one Iowa editor he knew well and wrote him in defense of his vote for the commission. This was H. C. Leighton of the Oskaloosa Herald, who had been very critical of the bill and of the Republicans in congress for supporting same. Strangely enough, Leighton at the time was the chairman of the Republican state committee, both he and his partner in ownership and publication of the Herald, William H. Needham, being staunch Republicans.

\section{Allison Urged Patience}

Leighton published an editorial in the Herald, of Feb. 8, 1877, which without doubt contained the Allison letter, although characterized therein as a "synopsis" or "simply the sentiments, thoughts and principles" outlined by Allison. The editorial stated that the Allison letter was private; also that "although we differ with him on the matter, we honor a man who has nerve enough to vote for his sentiments," evidencing a cooling off, perhaps because of Allison's further statement, 
"I am clear as to the wisdom and the propriety of the measure under the circumstances, and you will see before many moons that I am right." Leighton reported to his friends that the senator was not at all disturbed over the situation and was sure all would come out as he wished. Now, Allison never wrote about airy nothings. What he knew was important. In time it would be generally known.

Right then, late in February, something very important did happen. Judge Davis was a conscientious man. If he weighed the evidence and followed his conscience he would cast the deciding vote for the Hayes electors. But, to do so would bring upon his head the wrath of the whole Democrat party. He dared not sear his conscience by a vote for the Tilden electors. He was getting old. He wished to retire with a good name.

Judge Davis suddenly resigned from the supreme bench, which automatically took him off the electoral commission. The Illinois legislature gave him the consolation of election to the United States senate. The hopes of the Democrats vanished.

Southern State Governments to Democrats

For another chapter in the story, we move to another and a far different arena. To maintain order and permit civil government, as previously stated, Federal representatives had been sent into some of the Southern capitals. Stephen B. Packard, a young soldier from Maine, had been entrusted with this duty in Louisiana. He had permitted, while there, his name to be used as candidate for governor against Francis Nichols, the incumbent. Both candidates and their followers claimed the election. They set up state governments in nearby hotels and each proceeded to carry on. Each was prepared to send to Washington electoral election returns-one for Hayes and one for Tilden.

On March 1, Governor Packard received word that his cause for the governorship would be abandoned by the president. "At that time," stated the governor, 
many years later, in an interview with the present writer, "I had started out for a ride with my wife on the boulevard. As I was stepping to my carriage, a telegram was handed to me. It was from President Grant offering me the position of consul at the city of Mexico. I knew the long pending compromise had been effected. The Democrats had agreed to take over the Southern state governments in dispute and yield the presidency to the Republicans. Without waiting, I wrote my acceptance; and a few days later I was in Washington and on my way to Mexico."

Governor Packard also told me of the incident in which an ex-Confederate mixed with the crowd of his visitors and suddenly drew a revolver and fired directly at the governor; but Packard was then a spry young man and knocked the assailant's hand, deflecting the bullet.

Packard came to Iowa, located in Marshall county, and devoted himself to raising cattle. He became a member of the state board of agriculture and for many years supervised the cattle exhibits at the Iowa State Fair. It was during this time that he gave the interview.

The significance of these two major events lies in the fact that compromise was necessary to head off the Henry Watterson threat of taking over the national capital by bloody revolution. The Kentucky riflemen dared not start spattering blood over the capitol walls without the backing of the Southern Democratic state governments. When this menace was ended, there came a sudden end to the brag and bluster about another bloody revolution. The Kentuckians found their way home as best they could.

And, what about the electoral commission? After its organization, it had less than five weeks in which to do the impossible task of learning just what happened in a hundred remote precincts. Justice Clifford had been chosen president of the commission. Stephen P. Bradley became chief justice and thus a member of the commission. There were speeches and 
arguments, none of them going to the real issue. Very soon it became evident that the commission was marking time, awaiting the outcome of negotiations behind the scenes. The 44 th congress would come to an end by law at noon March 4 .

\section{Arbitration and Compromise}

Up to almost the last minute the electoral commission took no deciding vote: then it came- 7 to 8 . The decision was announced. Rutherford B. Hayes immediately was sworn in and became president. The commission was done; arbitration and compromise had saved the nation from another bloody attempt at its destruction.

But, the journalistic campaign to besmirch and blacken President Hayes did not end. The most dastardly thing in the whole record was done by Chas. A. Dana when he printed at the head of the New York Sun a picture of the president with the word "FRAUD" across the forehead. It was an unworthy piece of partisanship. Whatever else can be said of the whole procedure, it was not colored by any fraud, and to their credit, the shameful treatment of the new president was not condoned by all Democrats.

Iowans had an honorable part in guiding the ship of state through the stormy seas of awkward statesmanship. Notably, too, while Senator Allison for a time bore the brunt of savage criticism from members of his own party, he carried few scars of the conflict for any length of time, and his reputation for sagacity was not one whit diminished.

\section{The Dissemination of Knowledge}

Thirty and more years ago, Nicholas Murray Butler told his university trustees that:

"A university has three functions to perform ... to conserve knowledge; to advance knowledge; to disseminate knowledge. It falls short of the full realization of its aim unless, having provided for the conservation and advancement of knowledge, it makes no provision for its dissemination as well." 
Copyright of Annals of Iowa is the property of State of Iowa, by \& through the State Historical Society of Iowa and its content may not be copied or emailed to multiple sites or posted to a listserv without the copyright holder's express written permission. However, users may print, download, or email articles for individual use. 